\title{
PENGEMBANGAN MODEL PEMBELAJARAN PRAKARYA DAN KEWIRAUSAHAAN DENGAN PRINSIP THE GREAT YOUNG ENTREPRENEUR DI SMK UNTUK KURIKULUM 2013
}

\author{
Catarina Wahyu Dyah Purbaningrum \\ Universitas Gunungkidul \\ catarina_dyah@yahoo.com \\ Soenarto \\ Universitas Negeri Yogyakarta \\ soenarto@uny.ac.id
}

\begin{abstract}
Abstrak
Penelitian ini bertujuan: (1) menghasilkan model pembelajaran prakarya dan kewirausahaan dengan prinsip "The Great Young Entrepreneur" di SMK untuk Kurikulum 2013; (2) menghasilkan perangkat pembelajaran prakarya dan kewirausahaan di SMK untuk Kurikulum 2013 yang dapat menumbuhkan mental dan motivasi peserta didik untuk berwirausaha; (3) mengetahui tingkat kepraktisan model pembelajaran prakarya dan kewirausahaan dengan prinsip The Great Young Entrepeneur yang telah dikembangkan; dan (4) mengetahui tingkat keefektifan model pembelajaran prakarya dan kewirausahaan dengan prinsip The Great Young Entrepreneur yang telah dikembangkan. Hasil penelitian adalah sebagai berikut: (1) Model pembelajaran prakarya dan kewirausahaan dengan prinsip The Great Young Entrepreneur dapat digunakan dengan baik.(2) Perangkat pembelajaran yang dihasilkan yaitu: buku panduan model dan materi ajar. (3) Model pembelajaran prakarya dan kewirausahaan dengan prinsip TGYE dan perangkat pembelajaran berdasarkan hasil uji coba memenuhi kriteria praktis.(4) Model pembelajaran prakarya dan kewirausahaan dengan prinsip TGYE dan perangkat pembelajaran memenuhi kriteria efektif.
\end{abstract}

Kata kunci: pengembangan model pembelajaran, prakarya dan kewirausahaan, siswa SMK, Kurikulum 2013

\section{DEVELOPING A CRAFT AND ENTREPRENEURIAL LEARNING MODEL WITH THE PRINCIPLE OF "THE GREAT YOUNG ENTREPRENEUR" AT SMK FOR CURRICULUM 2013}

Abstract

The purposes of this study were (1) to produce a craft and entrepreneurship learning model with the principle of "The Great Young Entrepreneur" at SMK's for curriculum in 2013; (2) produce craft and entrepreneurial learning tools at SMK for curriculum 2013 that can grow mental and motivation of learners to be an entrepreneur; (3) determine the level of practicality of the learning model with the principle of "The Great Young Entrepreneur which was developed; and (4) determine the level of effectiveness of the learning model with the principle of the great young entrepreneur which was developed. The results of the study are as follows (1) Craft and entrepreneurial learning model with the principle "The Great Young Entrepreneur" can be used (starting from the beginning of the formatiom of groups up to business assistance through "The Great Young Entrepreneur" Community). (2) learning device resulting from the development of craft and entrepreneurial learning model with "The Great Young Entrepreneur" principle is guide book model and teaching materials. (3) craft and entrepreneurial learning model with "The Great Young Entreprenuer" principle and learning device based on the results meet the practicality criteria. (4) craft and entrepreneurial learning model with "The Great Young Entrepeneur" principle and learning device based on the results meet the criteria of effectiveness.

Keyword: developing learning model, a craft and entrepreneurial learning, students of SMK, curriculum 2013 



\section{PENDAHULUAN}

Pelajaran Prakarya dan Kewirausahaan diajarkan kepada semua siswa SMA/MA dan SMK/MAK sebagaimana tercantum dalam Kurikulum 2013. Pemberian materi ini antara lain untuk menumbuhkan semangat kewirausahaan sejak dini dan merupakan langkah yang baik untuk menyiapkan lahirnya lebih banyak lagi wirausaha di Indonesia. Pendidikan kewirausahaan sekarang ini diarahkan untuk menciptakan entrepreneur yang inovatif dan kreatif. Jika mencermati kompetensi inti dan kompetensi dasar mata pelajaran prakarya dan kewirausahaan Kurikulum 2013, pendidikan lebih ditekankan pada prakarya semata. Prakarya yang dipelajari di jenjang pendidikan menengah meliputi kerajinan, rekayasa, budidaya, dan pengolahan.

Meningkatnya keberhasilan pelajaran prakarya dan kewirausahaan di SMK ditandai dengan meningkatnya sikap kewirausahaan siswanya. Oleh sebab itu, diperlukan model pembelajaran yang lebih riil, yaitu memberikan mereka life skills. Life skills dalam pendidikan kewirausahaan adalah interaksi berbagai pengetahuan dan kecakapan yang sangat penting dimiliki oleh siswa sehingga mereka dapat hidup mandiri sebagai wirausahawan. Empat prinsip penting dalam menjalankan pembelajaran kewirausahaan sebagai life skills tidak boleh ditinggalkan, yaitu learning to know (belajar untuk mengetahui kewirausahaan), learning to do (belajar untuk melakukan kegiatan wirausaha), learning to be (belajar untuk mempraktekkan kegiatan wirausaha), and learning to live together (belajar untuk bersama dengan yang lain dalam interaksi sosial dalam berwirausaha).

Belajar merupakan komponen ilmu pendidikan yang berkenaan dengan tujuan dan bahan acuan interaksi, baik yang bersifat eksplisit maupun implisit (tersembunyi) (Sagala, 2010, p.11). Belajar adalah kegiatan yang dilakukan oleh seseorang agar memiliki kompetensi berupa keterampilan dan pengetahuan yang diperlukan. Belajar juga dapat dipandang sebagai sebuah proses elaborasi lingkungan alam. Belajar dirumuskan sebagai perubahan yang terjadi pada diri peserta didik. Perubahan ini bukan disebabkan oleh faktor alami melainkan oleh usaha sengaja yang berasal dari luar peserta didik yaitu berupa stimulus; dan perubahan yang terjadi dari dalam peserta didik (pengetahuan, sikap, keterampilan, dan aspirasi) yang merupakan respon terhadap stimulus itu

Dalam Peraturan Pemerintah Nomor 32 Tahun 2013 tentang Standar Nasional Pendidikan (SNP), tujuan penyelenggaraan SMK adalah menyiapkan siswa untuk memasuki lapangan kerja serta mengembangkan sikap profesional.

Dalam proses pembelajaran prakarya dan kewirausahaan dapat menumbuhkembangkan kewirausahaan pada siswa yang melakukan pelatihan baik di sekolah maupun secara magang. Perlakuan untuk mendidik wirausaha pada masa remaja adalah dengan pelatihan kecakapan kerja, sehingga siswa mampu memahami lingkungan kerja yang sesungguhnya dan kompetensi apa saja yang harus dimiliki untuk menjalankan perusahaan. Dari aspek pengetahuan siswa memahami teknik bidang usaha yang dimasuki, peran dan tanggung jawab manajemen dan organisasi bisnis, kepribadian dan kemampuan mandiri, sedangkan aspek keterampilan pada pelatihan meliputi mengatur teknik bidang usaha, keterampilan berkomunikasi, dan berinteraksi. Keterampilan ini memberikan arahan bahwa masalah sulitnya memperoleh pekerjaan dan timbulnya pengangguran tidak hanya diselesaikan dengan satu cara saja tetapi harus dihadapi dengan berbagai pendekatan disiplin keilmuan.

Persoalan utama dalam pengembangan pendidikan kewirausahaan adalah kesalahan dalam mengartikan kewirausahaan. Pada umumnya kewirausahaan hanya diartikan sebagai kemampuan menjalankan usaha secara mandiri. Karena pemahaman mengenai kewirausahaan hanya sedemikian sempit maka implementasi kurikulum dan silabus yang disusun untuk mengembangkan pendidikan kewirausahaan hanya sebatas bagaimana menjalankan usaha, bahkan ada yang diartikan keterampilan usaha.

Pembelajaran Prakarya dan Kewirausahaan merupakan salah satu mata pembelajaran yang bertujuan untuk menanamkan jiwa, sikap, dan etika wirausaha kepada peserta didik, memberikan bekal pengetahuan tentang kewirausahaan kepada peserta didik, memberi bekal keterampilan di bidang barang/jasa kepada peserta didik. Di samping itu, untuk melatih keterampilan berwirausaha kepada peserta didik melalui praktik berwira- 
usaha, mendorong dan menciptakan wirausahawan baru melalui proses pembelajaran yang didukung oleh dunia dan industri, mitramitra usaha dan dinas/instansi terkait, sehingga dapat menciptakan lapangan kerja atau usaha baru atau mengakses peluang kerja atau usaha yang ada.

Berdasarkan hasil observasi di lapangan dan analisis buku panduan guru dan siswa untuk mata pelajaran prakarya dan kewirausahaan SMK Kurikulum 2013, model pembelajaran kewirausahaan yang dilakukan di sekolah menengah masih menggunakan model pembelajaran yang konvensional, belum mampu menumbuhkan sikap dan perilaku wirausaha siswa sekolah menengah. Model pembelajaran kewirausahaan sudah sedikit dimodifikasi dengan praktik menjual. Untuk menumbuhkan sikap dan perilaku wirusaha siswa sekolah menengah perlu dirancang model pembelajaran yang mampu meningkatkan prestasi belajar juga mampu menumbuhkan sikap dan perilaku wirausaha dengan cara pengintegratasian ciri-ciri wirausaha ke dalam model pembelajaran untuk diimplementasikan di sekolah menengah. Diintegrasikannya ciriciri wirausaha ke dalam model pembelajaran diharapkan dapat menumbuhkembangkan sikap dan perilaku wirausaha pada siswa sekolah menengah kejuruan.

Kurikulum dan silabus serta sarana dan prasarana pendidikan belum memadai untuk melaksanakan pelajaran prakarya dan kewirausahaan, dampak dari pelajaran prakarya dan kewirausahaan ini belum tampak signifikan menjadikan seseorang menjadi entrepreneur. Peserta didik bertambah pengetahuannya, meningkat keterampilannya, namun mental ability, aptitude dan attitude belum banyak berubah. Temuan menunjukkan bahwa perubahan minat wirausaha siswa ditunjukkan oleh beberapa indikator minat wirausaha siswa di antaranya adalah kemauan keras untuk mencapai tujuan dan kebutuhan hidup, keyakinan atas kekuatan sendiri, ketahanan fisik dan mental, ketekunan dan keuletan bekerja dan berusaha, pemikiran yang kreatif dan konstruktif, serta berani mengambil risiko. Indikator sikap jujur dan tanggung jawab serta berorientasi ke masa depan belum mengalami peningkatan.

Oleh karena itu dengan adanya mata pelajaran prakarya dan kewirausahaan, peneliti akan mengembangkan model pembel- ajaran prakarya dan kewirausahaan SMK/ MAK Kurikulum 2013 dengan pendekatan The Great Young Entrepreneur yang akan dikembangkan lebih berfokus pada pengembangan personal sebagai inti dari pendidikan kewirausahaan.

The Great Young Entrepreneur (TGYE) adalah konsep yang dibentuk untuk memberikan sebuah pembelajaran prakarya dan kewirausahaan yang diharapkan menghasilkan entrepreneur-entrepreneur muda yang sukses (Great Young Entrepreneur). Great Young Entrepreneur ini tidak hanya dilihat dari kapasitas atau besar kecilnya usaha yang dimiliki, akan tetapi lebih dari itu, yaitu merupakan sebuah pola pikir dan pola tindakan yang menghasilkan kreativitas dan inovasi, bertujuan untuk senantiasa memberikan nilai tambah dari setiap sumber daya yang ada.

Dalam pembelajaran prakarya dan kewirausahaan para peserta didik akan didampingi guru mulai dari merencanakan usaha, memulai, membangun, merawat usaha sampai pada akhirnya usaha mereka bisa berjalan sendiri. Dalam pembelajaran dibentuk wadah kegiatan yang disebut Great Young Entepreneur Community yang dibentuk sebagai sebuah organisasi (komunitas) dengan tujuan sebagai wadah kepentingan usaha anggotanya. Kurikulum dan silabus serta sarana dan prasarana pendidikan yang mendukung pelaksanaan pendidikan kewirausahaan dimaksudkan untuk meningkatkan mental ability, aptitude dan attitude yang nantinya diharapkan akan meningkatkan lulusan yang mampu menjadi seorang pengusaha walaupun mulai dari yang kecil-kecil sehingga menjadi beberapa pengusaha yang lebih besar lagi.

Prinsip pelaksanaan pendidikan kejuruan merupakan proses pembudayaan dalam pembentukan kebiasaan kerja dan kebiasaan berpikir benar. Hal ini dilakukan secara berkelanjutan sehingga pelatihan dan pengalaman yang diberikan dapat efisien untuk mencapai tujuan.

Kurikulum 2013 mengamanatkan esensi pendekatan saintifik dalam pembelajaran. Pendekatan saintifik diyakini sebagai titian emas perkembangan dan pengembangan sikap, keterampilan, dan pengetahuan peserta didik. Dalam pendekatan atau proses kerja yang memenuhi kriteria ilmiah, para ilmuan lebih mengedepankan penalaran induktif (in- 
ductive reasoning) dibandingkan dengan penalaran deduktif (deductivereasoning).

Mata Pelajaran Prakarya dan Kewirausahaan dapat digolongkan ke dalam pengetahuan transcience-knowledge. Hal ini yaitu mengembangkan pengetahuan dan melatih keterampilan kecakapan hidup berbasis seni, teknologi, dan ekonomi.

Belajar merupakan komponen ilmu pendidikan yang berkenaan dengan tujuan dan bahan acuan interaksi, baik yang bersifat eksplisit maupun implisit (Sagala, 2010,p.11). Belajar adalah kegiatan yang dilakukan oleh seseorang agar memiliki kompetensi berupa keterampilan dan pengetahuan yang diperlukan. Istilah belajar yang digunakan dalam penelitian ini adalah proses belajar yang sengaja diciptakan, bukan belajar yang terjadi secara spontan. Untuk dapat berlangsung efektif dan efisien, proses belajar perlu dirancang menjadi sebuah kegiatan pembelajaran.

Pembelajaran didefinisikan sebagai " $a$ set of events embedded in purposeful activities that facilitate learning" (Gagne,2005,p.1). Pembelajaran adalah serangkaian aktivitas yang sengaja diciptakan dengan maksud untuk memudahkan terjadinya proses belajar. Pembelajaran juga dimaknai sebagai aktivitas atau kegiatan yang berfokus pada kondisi dan kepentingan pembelajar (learner centered) (Miarso, 2005, p.144). Istilah pembelajaran digunakan untuk menggantikan istilah "pengajaran" yang lebih bersifat sebagai aktivitas yang berfokus pada guru (teacher centered).

Model pembelajaran adalah kerangka konseptual yang melukiskan prosedur yang sistematis dalam mengorganisasikan pengalaman belajar untuk mencapai tujuan belajar tertentu, dan berfungsi sebagai pedoman bagi para perancang pembelajaran dan para pengajar dalam merencanakan aktivitas belajar. Berdasarkan pendapat tersebut dapat disimpulkan bahwa model pembelajaran adalah kerangka konseptual yang melukiskan pola atau prosedur secara sistematis dalam mengorganisasikan pembelajaran yang berfungsi sebagai pedoman bagi para pengajar dalam merencanakan dan melaksanakan pembelajaran.

Kewirausahaan adalah suatu proses penerapan kreativitas dan inovasi dalam memecahkan persoalan dan menemukan peluang untuk memperbaiki kehidupan. Kewirausahaan adalah segala hal yang berkaitan dengan sikap, tindakan, dan proses yang dilakukan oleh para entrepreneur dalam merintis, menjalankan dan mengembangkan usaha mereka (Nasution, 2007, p.4). Esensi dari kewirausahaan adalah menciptakan nilai tambah di pasar melalui proses pengkombinasian sumber daya dengan cara-cara baru dan berbeda agar dapat bersaing.

Wirausaha yang sukses pada umumnya adalah mereka yang memiliki kompetensi dalam ilmu pengetahuan, keterampilan, dan kualitas individu yang meliputi sikap, motivasi, nilai serta tingkah laku yang diperlukan untuk melaksanakan pekerjaan/ kegiatan. Hal tersebut sesuai dengan pernyataan Suryana (2008, p.4) bahwa seorang wirausaha tidak akan berhasil apabila tidak memiliki pengetahuan, kemampuan, dan kemauan.

Berdasarkan beberapa definisi tersebut maka dapat disimpulkan bahwa kompetensi kewirausahaan merupakan karakteristik yang mendasar dari seseorang individu dalam menciptakan peluang dan kesempatan secara kreatif dan inovatif, kemampuan mengumpulkan sumberdaya, mengubah peluang menjadi keuntungan di bawah kondisi risiko dan ketidakpastian.

Pembelajaran Prakarya dan Kewirausahaan merupakan pelajaran vokasional, yaitu pelajaran untuk memberikan pengetahuan, sikap dan keterampilan kerja bagi siswanya. Kompetensi yang diharapkan adalah mampu melakukan kegiatan ekonomi-produktif setelah mereka memasuki dunia kerja.

Konsep The Great Young Entrepreneur (TGYE) merupakan sebuah konsep yang dibangun dari Great Sistem dan Great Human. The Great Young Entrepreneur (TGYE) adalah konsep yang dibentuk untuk memberikan sebuah pembelajaran prakarya dan kewirausahaan yang diharapkan menghasilkan entrepreneur-entrepreneur muda yang sukses (Great Young Entrepreneur).

Pengembangan model pembelajaran prakarya dan kewirausahaan dengan prinsip The Great Young Entrepreneur ini mengembangkan model pembelajaran Project Based Learning (PjBL). Peserta didik dibagi menjadi beberapa kelompok, kemudian diberikan pembelajaran tentang enam sintaks kewirausahaan seperti identifikasi peluang usaha, membuat rencana usaha, menjalin kerja sama usaha, produksi, pemasaran, dan analisis hasil usaha. Selanjutnya, mereka akan didampingi mulai 
merencanakan usaha, memulai, membangun, merawat usaha sampai pada akhirnya usaha mereka bisa berjalan dan berkembang melalui unit usaha yang ada di sekolah. Alat yang digunakan dalam pendampingan ini adalah Great Young Entepreneur Community yang akan dibentuk sebagai sebuah organisasi (komunitas) dengan tujuan kepentingan usaha anggotanya. Dalam proses keberlangsungan mereka memulai usaha, mereka akan tetap didampingi dengan menggunakan alat Great Young Entrepreneur Community. Di komunitas inilah mereka melakukan diskusi, tanya jawab, evaluasi, usaha (bisnis), dan melakukan strategi-strategi pemecahan masalah dan pengembangan usaha.

\section{METODE PENELITIAN}

Penelitian ini merupakan jenis penelitian Riset and Development. Pengembangan yang dimaksud adalah suatu langkah berurutan yang bertujuan untuk mewujudkan suatu rancangan pembelajaran dalam bentuk struktur model. Model pengembangan adalah suatu langkah berurutan yang bertujuan untuk mewujudkan suatu rancangan pembelajaran dalam bentuk struktur model. Menurut Gay (1990, p.10) bahwa penelitian dan pengembangan model di bidang pendidikan bukan untuk menguji hipotesis, tetapi untuk menghasilkan produk pendidikan yang secara efektif dan efisien dapat dimanfaatkan di sekolah.

Uji coba perorangan dilakukan di SMK Ma'arif Ponjong dan uji coba terbatas lokasi yang dipilih adalah SMK Negeri 1 Wonosari. Subjek dalam penelitian adalah siswa kelas $\mathrm{X}$ SMK 1 Wonosari. Penelitian ini dilakukan pada bulan September 2014 sampai dengan April 2015.

Instrumen yang digunakan dikembangkan melalui Focus Group Discussion (FGD), yang merupakan diskusi untuk mengemukakan pendapat yang para peserta menyampaikan gagasan secara terbuka mengenai sesuatu hal hingga di antara peserta terjadi kesepakatan. Peserta FGD adalah orang-orang yang dipandang memiliki keahlian dalam bidang yang akan diteliti, sehingga memberikan sumbangan pemikiran yang memadai. Diskusi dalam FGD ini dapat digunakan sebagai satu tahap dari need assessment. Teknik ini digunakan dengan harapan dapat diperoleh instrumen yang valid dan reliabel dengan melibatkan pakar di bidangnya.

Selanjutnya, instrumen yang sudah valid dan reliabel tersebut digunakan untuk mengukur valid, praktis, dan efektif model pembelajaran prakarya dan kewirausahaan dengan prinsip TGYE. Validitas menggunakan instrumen lembar validasi, praktisnya menggunakan instrumen lembar penilaian kepraktisan model pembelajaran prakarya dan kewirausahaan dengan prinsip TGYE oleh ahli \& praktisi dan lembar observasi. Kepraktisan model menggunakan instrumen lembar observasi tentang keterlaksanaan model pembelajaran prakarya dan kewirausahaan dengan prinsip The Great Young Entrepreneur. Keefektifan model menggunakan instrumen: (1) lembar observasi siswa dalam pembelajaran; (2) lembar observasi guru dalam mengelola pembelajaran; (3) angket respon siswa terhadap penerapan model; (4) angket respon guru terhadap penerapan model.

Pada pra pengembangan, dipilih teknik observasi, dan dokumentasi, di samping kajian literatur. Secara umum, kedua teknik tersebut (observasi dan dokumentasi) digunakan secara bersamaan dan saling melengkapi. Data berupa deskriptif kualitatif ataupun kuantitatif. Pada tahap pengembangan, langkah yang digunakan adalah pengumpulan data melalui uji coba terbatas. Pada uji coba terbatas, teknik pengumpulan data yang pokok adalah observasi dan angket. Angket diberikan kepada guru prakarya dan kewirausahaan dan juga siswa dengan tujuan untuk mengetahui keterterapan desain model serta kendala yang dihadapi. Observasi dilakukan guru pengamat dan peneliti terhadap proses penerapan desain model, untuk mengetahui apakah desain model dapat diterapkan secara benar.

Sebelum instrumen digunakan di lapangan untuk mengukur kevalidan, keterlaksanaan dan keefektifan model, terlebih dahulu diuji validitas dan reliabiltasnya. Namun, validitas instrumen yang berbentuk format validasi, lembar observasi, dan angket hanya diuji validitas teorinya melalui penilaian para ahli dan praktisi. Analisis yang diperlukan adalah Analisis Keterlaksanaan Model

Model dikatakan praktis dan mudah dilaksanakan apabila: (1) menurut penilaian praktisi model dapat dengan mudah dilaksanakan dengan sedikit revisi; (2) secara nyata di lapangan model dapat diterapkan dan dapat 
terlaksana sebagian walaupun tidak semua berdasarkan pengamatan; (3) kemampuan guru mengelola pembelajaran dengan menggunakan model termasuk kategori minimal cukup baik.

Model pembelajaran dikatakan efektif jika menurut penilaian praktisi berdasarkan pengetahuan dan pengalamannya model yang dikembangkan efektif dan secara nyata di kelas pelaksanaannya efektif. Indikatornya adalah: (1) tujuan dari penerapan model pembelajaran tercapai (2) respon siswa terhadap model yang diungkapkan dalam perasaan, pendapat dan komentar positif; (3) respon guru terhadap model yang diungkapkan dalam perasaan, pendapat dan komentar positif

Validitas setiap aspek atau keseluruhan aspek yang dinilai ditetapkan berdasarkan kriteria pengkategorian model yang diadaptasi dari pengategorian Bloom, Madaus \& Hasting (1981) sebagai berikut:

$$
\begin{aligned}
& 0,80 \leq \mathrm{Va}<1.00 \text { sangat valid } \\
& 0,60 \leq \mathrm{Va}<0,80 \text { valid } \\
& 0,40 \leq \mathrm{Va}<0,60 \text { cukup valid } \\
& 0,20 \leq \mathrm{Va}<0,40 \text { kurang valid } \\
& 0,00 \leq \mathrm{Va}<0,20 \text { tidak valid }
\end{aligned}
$$

Kriteria yang digunakan untuk memutuskan bahwa instrumen yang digunakan memiliki derajad validitas yang memadai apabila nilai Va berada dalam skor 0,60 sampai 1.00. Bila tidak demikian maka perlu dilakukan revisi berdasarkan saran dari validator atau dengan melihat aspek-aspek yang dinilai kurang. Selanjutnya, dilakukan validasi ulang kemudian dianalisis kembali. Demikian seterusnya sampai diperoleh nilai rerata dalam kategori minimal valid.

Untuk mengukur tingkat kesepakatan antarpenilai terhadap hasil validasi instrumen oleh para ahli (expert), dianalisis dengan statistik Coeffisient Cohen"s Kappa dan Percentage of Agreements dari Nitko dan Brokhatr (2007, p.80). Lembar penilaian dikatakan reliabel jika koefisien reliabilitasnya $(\mathrm{R}) \geq 0,70$.

\section{HASIL PENELITIAN DAN PEMBAHASAN}

\section{Hasil Observasi Aktivitas Siswa dalam Pembelajaran}

Keefektifan model pembelajaran prakarya dan kewirausahaan dengan prinsip TGYE ditunjukkan oleh aktivitas siswa dalam pembelajaran. Hasil observasi aktivitas siswa menunjukkan bahwa 93\% siswa dapat melaksanakan model pembelajaran ini.

Memang pada saat awal pertemuan siswa masih tampak bingung dengan model pembelajaran prakarya dan kewirausahaan dengan prinsip TGYE. Namun, setelah buku materi dibagikan dan guru menjelaslan mekanismenya akhirnya siswa dapat memahami model pembelajaran ini.

Pada pertemuan selanjutnya siswa tampak senang sekali mengikuti model pembelajaran ini dan pada saat pelaksanaan The Great Young Entrepreneur Community siswa nampak antusias. Menurut siswa mereka merasa senang dan terbantu dengan adanya komunitas wirausaha ini, karena selain dapat menjadi wadah untuk aktivitas bisnis mereka, komunitas ini juga bisa dijadikan sebagai sarana untuk berdiskusi dan mencari solusi bersama atas kegiatan bisnis yang sudah mereka lakukan.

\section{Respon Siswa terhadap Model Pembelajaran}

Berdasarkan hasil analisis angket respon siswa terhadap pelaksanaan pembelajaran, bahwa siswa merespon baik. Hal ini dilihat dari tanggapan siswa sebelum dan setelah pelaksanaan model pembelajaran yang menunjukkan ada perubahan tanggapan. Ratarata siswa menilai tidak setuju bahwa pembelajaran prakarya dan kewirausahaan dapat menumbuhkan jiwa kewirausahaan mereka sebelum pelaksanaan model. Akan tetapi ratarata siswa menilai bahwa menggunakan model pembelajaran prakarya dan kewirausahaan dengan prinsip TGYE bisa menumbuhkan jiwa kewirausahaan mereka setelah penggunaanya.

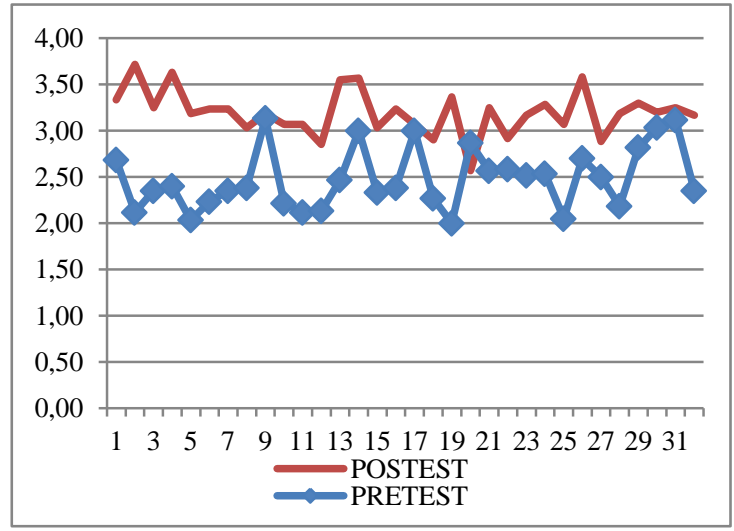

Gambar 1. Respon Siswa terhadap Model Pembelajaran 
Tabel 1. Hasil Observasi Keterlaksanaan Model

\begin{tabular}{|c|c|c|c|c|c|c|c|c|c|c|c|c|}
\hline Aspek Pengamatan & RPP 1 & Ket & RPP 2 & Ket & RPP 3 & Ket & RPP 4 & Ket & RPP 5 & Ket & RPP 6 & Ket \\
\hline $\begin{array}{ll}\text { I. } & \text { PENDAHULUAN }\end{array}$ & & & & & & & & & & & & \\
\hline 1. Apakah guru memuka pelajaran dengan doa? & 1 & TL & 1 & TL & 1 & TL & 1 & TL & 1 & $\mathrm{TL}$ & 1 & TL \\
\hline $\begin{array}{l}\text { 2. Apakah guru memberi penjelasan kepada } \\
\text { siswa mengenai kompetensi dasar? }\end{array}$ & 1 & TL & 1 & TL & 1 & TL & 1 & TL & 1 & $\mathrm{TL}$ & 1 & TL \\
\hline $\begin{array}{l}\text { 3. Apakah guru menjelaskan tujuan } \\
\text { pembelajaran dan teknis belajar? }\end{array}$ & 1 & TL & 1 & TL & 1 & $\mathrm{TL}$ & 1 & $\mathrm{TL}$ & 1 & $\mathrm{TL}$ & 1 & $\mathrm{TL}$ \\
\hline 4. Apakah guru memotivasi siswa? & 1 & $\mathrm{TL}$ & 1 & $\mathrm{TL}$ & 1 & $\mathrm{TL}$ & 1 & $\mathrm{TL}$ & 1 & $\mathrm{TL}$ & 1 & $\mathrm{TL}$ \\
\hline \multicolumn{13}{|l|}{ II. $\quad$ KEGIATAN INTI } \\
\hline $\begin{array}{l}\text { 1. Guru mengorganisasikan siswa ke dalam } \\
\text { kelompok }\end{array}$ & 1 & TL & 1 & TL & 1 & $\mathrm{TL}$ & 1 & $\mathrm{TL}$ & 1 & $\mathrm{TL}$ & 1 & $\overline{T L}$ \\
\hline $\begin{array}{l}\text { 2. Guru mengorganisasikan siswa untuk } \\
\text { melakukan tugas berwirausaha sesuai dengan } \\
\text { sintaks }\end{array}$ & 1 & $\mathrm{TL}$ & 1 & TL & 1 & $\mathrm{TL}$ & 1 & TL & 1 & TL & 1 & $\mathrm{TL}$ \\
\hline $\begin{array}{l}\text { 3. Siswa aktif dalam kegiatan berwirausaha } \\
\text { sesuai sintaks }\end{array}$ & 1 & $\mathrm{TL}$ & 1 & $\mathrm{TL}$ & 1 & $\mathrm{TL}$ & 1 & $\mathrm{TL}$ & 1 & $\mathrm{TL}$ & 1 & $\mathrm{TL}$ \\
\hline $\begin{array}{l}\text { 4. Adanya interaksi aktif siswa-siswa, guru- } \\
\text { siswa, dan antar kelompok }\end{array}$ & 1 & $\mathrm{TL}$ & 1 & $\mathrm{TL}$ & 1 & $\mathrm{TL}$ & 1 & $\mathrm{TL}$ & 1 & $\mathrm{TL}$ & 1 & $\mathrm{TL}$ \\
\hline $\begin{array}{l}\text { 5. Guru membantu siswa yang kesulitan } \\
\text { memahami tugas-tugas? }\end{array}$ & 1 & $\mathrm{TL}$ & 1 & TL & 1 & $\mathrm{TL}$ & 1 & $\mathrm{TL}$ & 1 & TL & 1 & $\mathrm{TL}$ \\
\hline $\begin{array}{l}\text { 6. Guru memantau siswa dalam melaksanakan } \\
\text { kegiatan berwirausaha sesuai dengan sintaks }\end{array}$ & 1 & $\mathrm{TL}$ & 1 & TL & 1 & $\mathrm{TL}$ & 0,5 & TL & 1 & TL & 1 & $\mathrm{TL}$ \\
\hline 7. Guru memberikan umpan balik kepada siswa & 1 & TL & 1 & $\mathrm{TL}$ & 1 & $\mathrm{TL}$ & 1 & $\mathrm{TL}$ & 1 & $\mathrm{TL}$ & 1 & $\mathrm{TL}$ \\
\hline 8. Guru mengajar sesuai dengan RPP & 1 & $\mathrm{TL}$ & 1 & $\mathrm{TL}$ & 1 & $\mathrm{TL}$ & 1 & $\mathrm{TL}$ & 1 & $\mathrm{TL}$ & 1 & $\mathrm{TL}$ \\
\hline \multicolumn{13}{|l|}{ III. $\quad$ PENUTUP } \\
\hline $\begin{array}{l}\text { 1. Apakah guru mendiskusikan pengalaman } \\
\text { belajar pada akhir pertemuan? }\end{array}$ & 1 & TL & 0,5 & TL & 0,5 & $\mathrm{TL}$ & 1 & TL & 1 & TL & 1 & TL \\
\hline $\begin{array}{l}\text { 2. Apakah guru tetap menjaga kelas agar tetap } \\
\text { aktif dan kondusif? }\end{array}$ & 1 & $\mathrm{TL}$ & 1 & TL & 1 & TL & 0,5 & TL & 1 & TL & 1 & TL \\
\hline $\begin{array}{l}\text { 3. Apakah guru dan siswa bersama-sama } \\
\text { melakukan analisis sintaks yang dilaksanakan }\end{array}$ & 1 & TL & 0,5 & TL & 0,5 & TL & 1 & TL & 1 & TL & 1 & $\mathrm{TL}$ \\
\hline 4. Apakah guru menutup pelajaran dengan doa? & 1 & $\mathrm{TL}$ & 1 & $\mathrm{TL}$ & 1 & $\mathrm{TL}$ & 1 & $\mathrm{TL}$ & 1 & $\mathrm{TL}$ & 1 & $\mathrm{TL}$ \\
\hline
\end{tabular}

Tabel 2. Hasil Pengamatan Aktivitas Guru dalam Pembelajaran

\begin{tabular}{|c|c|c|c|c|c|c|c|c|}
\hline \multirow{2}{*}{\multicolumn{2}{|c|}{ No Aspek Teramati }} & \multicolumn{6}{|c|}{ Pertemuan ke- } & \multirow[t]{2}{*}{ Ket } \\
\hline & & 1 & 2 & 3 & 4 & 5 & 6 & \\
\hline I. & Pendahuluan & & & & & & & 3.66 \\
\hline 1 & Apakah guru membuka pelajaran dengan doa? & 4 & 4 & 4 & 4 & 4 & 4 & 4.00 \\
\hline 2 & Apakah guru memberi penjelasan kepada siswa mengenai & 4 & 4 & 4 & 3 & 3 & 4 & 3.66 \\
\hline 3 & kompetensi dasar? & 4 & 3 & 3 & 3 & 4 & 3 & 3.33 \\
\hline 4 & $\begin{array}{l}\text { Apakah guru menjelaskan tujuan pembelajaran dan teknis } \\
\text { belajar? }\end{array}$ & 4 & 3 & 3 & 4 & 4 & 4 & 3.66 \\
\hline
\end{tabular}

Apakah guru memotivasi siswa?

\begin{tabular}{|c|c|c|c|c|c|c|c|c|}
\hline \multicolumn{8}{|c|}{ II. Kegiatan Inti } & \multirow{2}{*}{$\frac{3.72}{3.83}$} \\
\hline 1 & Guru menjelaskan pokok bahasan dengan singkat & 4 & 4 & 4 & 4 & 3 & 4 & \\
\hline 2 & Guru menjelaskan materi pokok dalam modul & 4 & 4 & 4 & 3 & 3 & 4 & 3.66 \\
\hline $\begin{array}{l}3 \\
4\end{array}$ & $\begin{array}{l}\text { Apakah guru memberikan waktu kepada siswa untuk belajar } \\
\text { mandiri dengan modul? }\end{array}$ & 4 & 4 & 4 & 4 & 4 & 3 & 3.83 \\
\hline 5 & Apakah guru membentuk kelompok diskusi? & 4 & 3 & 3 & 3 & 4 & 3 & 3.33 \\
\hline 6 & Apakah guru membantu siswa yang kesulitan memahami tugas- & 4 & 3 & 3 & 4 & 3 & 4 & 3.50 \\
\hline 7 & tugas? & 4 & 4 & 4 & 3 & 4 & 4 & 3.83 \\
\hline \multirow[t]{2}{*}{8} & Apakah guru melayani jika ada pertanyaan dan pendapat dari & 4 & 4 & 4 & 4 & 4 & 4 & 4.00 \\
\hline & $\begin{array}{l}\text { siswa? } \\
\text { Apakah guru memberikan umpan balik kepada siswa? } \\
\text { Apakah guru mengajar sesuai dengan RPP? }\end{array}$ & 4 & 4 & 4 & 3 & 4 & 4 & 3.83 \\
\hline \multicolumn{8}{|c|}{ III. Penutup } & $\mathbf{3 . 8 7}$ \\
\hline 1 & Apakah guru mendiskusikan pengalaman belajar pada akhir & 4 & 4 & 4 & 4 & 4 & 4 & 4.00 \\
\hline 2 & pertemuan? & 4 & 4 & 4 & 3 & 3 & 4 & 3.66 \\
\hline 3 & Apakah guru tetap menjaga kelas agar tetap aktif dan kondusif? & 4 & 4 & 4 & 4 & 4 & 3 & 3.83 \\
\hline \multirow[t]{2}{*}{4} & $\begin{array}{l}\text { Apakah guru memberikan informasi untuk pertemuan } \\
\text { berikutnya? }\end{array}$ & 4 & 4 & 4 & 4 & 4 & 4 & 4.00 \\
\hline & Apakah guru menutup pelajaran dengan doa? & & & & & & & \\
\hline
\end{tabular}




\section{Respon Guru terhadap Model Pembelajaran}

Data hasil respon guru menunjukkan bahwa guru memberikan tanggapan positif dan menyatakan setuju bahwa model pembelajaran prakarya dan kewirausahaan dengan prinsip TGYE. Prinsip ini mampu menumbuhkan motivasi siswa untuk berwirausaha.

\section{SIMPULAN DAN SARAN}

Berdasarkan uraian hasil penelitian dan pembahasan yang telah dipaparkan, maka simpulan penelitian ini adalah sebagai berikut. Pertama, model pembelajaran prakarya dan kewirausahaan dengan prinsip The Great Young Entrepreneur dapat digunakan dengan baik (mulai dari awal pembentukan kelompok sampai dengan pendampingan usaha melalui The Great Young Entrepreneur Community).

Kedua, perangkat pembelajaran yang dihasilkan dari pengembangan model pembelajaran prakarya dan kewirausahaan dengan prinsip TGYE yaitu: buku panduan model, rencana pelaksanaan pembelajaran (RPP), dan materi ajar. Ketiga, model pembelajaran prakarya dan kewirausahaan dengan prinsip TGYE dan perangkat pembelajaran berdasarkan hasil uji coba memenuhi kriteria praktis yang ditunjukkan oleh hasil penilaian para ahli, keterlaksanaan model pembelajaran dan kemampuan guru dalam mengelola pembelajaran. Keempat, model pembelajaran prakarya dan kewirausahaan dengan prinsip TGYE dan perangkat pembelajaran berdasarkan hasil uji coba memenuhi kriteria efektif yang ditunjukkan oleh aktivitas siswa dalam pembelajaran.

\section{Saran}

Berdasarkan simpulan penelitian, peneliti memberikan beberapa saran kepada peneliti dan praktisi yang berminat untuk menerapkan model pembelajaran prakarya dan kewirausahaan dengan prinsip TGYE dalam pelaksanaan pembelajaran sebagai berikut. Pertama, Musyawarah Guru Mata Pelajaran (MGMP) dapat menyosialisasikan model ini kepada kepala-kepala sekolah SMK dan guruguru bidang studi dalam rangka mengembangkan mental kewirausahaan peserta didik, menumbuhkan motivasi peserta didik untuk berwirausaha. Kedua, model pembelajaran prakarya dan kewirausahaan dengan prinsip TGYE yang dihasilkan, belum diimplementasikan secara luas di sekolah-sekolah, khususnya Sekolah Menengah Kejuruan (SMK). Oleh karena itu, untuk mengetahui keefektifan model pembelajaran prakarya dan kewirausahaan dengan prinsip TGYE, disarankan kepada para guru dan peneliti lainnya untuk mengimplementasikan model pembelajaran prakarya dan kewira-usahaan dengan prinsip TGYE dan perangkat pembelajarannya pada ruang lingkup yang lebih luas di sekolahsekolah, khususnya di SMK. Dengan demikian, hasil-hasil penelitian yang terkait dengan model pembelajaran prakarya dan kewirausahaan dengan prinsip TGYE dapat dijadikan referensi untuk mengembangkan model pembelajaran prakarya dan kewirausahaan lainnya.

Ketiga, guru yang berupaya untuk mengembangkan mental kewirausahaan peserta didik dan menumbuhkan motivasi peserta didik untuk berwirausaha, dapat menerapkan model pembelajaran prakarya dan kewirausahaan dengan prinsip TGYE sebagai salah satu alternatif jawaban permasalahan tersebut. Keempat, dalam menerapkan pembelajaran dengan model ini membutuhkan waktu pembelajaran 12 x 45 menit, agar pengamatan lebih maksimal dalam melihat dan mengamati proses pembelajaran dengan baik.

\section{DAFTAR PUSTAKA}

Gagne, R, M. (2005). The Principles of instructional design. New York: Wadsworth Publishing Co.

Gay, L.R. (1990). Educational research: Competence analysis and application, $3^{\text {th }}$ edition. Singapore: Macmilaan Pub

Miarso, Y. (2005). Landasan Berpikir dan Pengembangan Teori dalam Penelitian Kualitatif. Jurnal Pendidikan Penabur No. 05/IVDesember/2005 63-71 diakses dari http://bpkpenabur.or.id/wpcontent/uploads/2015/10/jurnal-No05IV-Desember2005.pdf

Nasution, A.H., B.N., \& Suef, Mukh. (2007). Entrepreneurship, membangun spirit teknopreneurship. Yogyakarta: Andi Offset. 
Nitko, A.J., \& Brookhart, S.M. (2007). Educational assessment of students. New Jersey: Person Merrill Prentice Hall

Republik Indonesia (2013). Undang-undang Nomor 32 Tahun 2013 tentang Sistem Pendidikan Nasional.
Sagala, S. (2010). Konsep dan makna pembelajaran: Untuk membantu memecahkan problematika belajar dan mengajar. Bandung: Alfabeta.

Suryana. (2008). Kewirausahaan: Pedoman praktis, kiat dan proses menuju sukses. Jakarta: Salemba Empat. 